\title{
A MÉRNÖKKÉPZÉS OKTATÁSI MÓDSZEREI
}

\section{EDUCATIONAL METHODS OF ENGINEERING TRAINING}

\author{
Bagyinszki Gyula, ${ }^{1}$ Bitay Enikő ${ }^{2}$ \\ ${ }^{1}$ Óbudai Egyetem, Bánki Donát Gépész és Biztonságtechnikai Mérnöki Kar, Budapest, Magyarország, \\ bagyinszki.gyula@bgk.uni-obuda.hu \\ ${ }^{2}$ Sapientia Erdélyi Magyar Tudományegyetem, Marosvásárhelyi Kar, Marosvásárhely, Románia, \\ ebitay@ms.sapientia.ro
}

\begin{abstract}
The choice and the appropriate combination of methods used in the teaching-learning (education - knowledge-acquisition) process in technical higher education depends to a large extent on the personality of the lecturer, his/her pedagogical culture, personal competences and of course, the technical possibilities at his/ her disposal. This study provides a concise overview of the methods as tried-and-tested systems of consciously implemented operations and means that are systematically used by the lecturer to achieve the objectives of training in practical cooperation with the students.
\end{abstract}

Keywords: education, method, lecturer, student.

\section{Összefoglalás}

A műszaki felsőoktatás tanítási-tanulási (képzési-ismeretelsajátítási) folyamatában alkalmazható módszerek megválasztása és célszerű kombinálása nagy mértében függ az oktató személyiségétől, pedagógiai kulturáltságától, személyes kompetenciáitól és természetesen a rendelkezésére álló technikai lehetőségektől. Jelen közlemény a módszerek - mint tudatosan megvalósított műveletek és eszközök kipróbált rendszerei - választékáról nyújt tömör áttekintést, amelyeket az oktató a képzési célok elérése érdekében szisztematikusan alkalmaz(hat), célszerű kooperációban a hallgatókkal.

Kulcsszavak: oktatás, módszer, oktató, hallgató.

\section{Bevezetés}

Ha az oktatók és a hallgatók tevékenységét tekintjük az oktatási folyamatban, a „műveleteik” négy fő csoportját, fajtáját különböztethetjük meg [1]:

a) az oktatók részéről:

- a kész információk szóbeli közlését és/vagy írásos formában való hozzáférhetővé tételét,

- a megismerési problémák megoldási folyamatának irányítását,

- a tudományos, társadalmi, etikai és esztétikai értékek kiemelését,

-a hallgatók gyakorlati tevékenységének szervezését.

b) a hallgatók részéről a felsoroltaknak megfelelően:

- a „kész” tartalmak tanulását és az ismeretek elsajátítását, -a problémák megoldását, az összefüggések feltárását és az itt szerzett ismeretek elsajátítását, - az értékek megismerését és átgondolását,

- a tárgyak alakítását.

\section{Módszerek csoportosítása}

A tanítási-tanulási (képzési-ismeretelsajátítási) folyamatban alkalmazható módszerek egy lehetséges csoportosítása az [1, 2] alapulvételével a következő:

\section{Közlő (szövegen alapuló) módszerek:}

1. előadás

2. tankönyv-, ill. jegyzetfeldolgozás

3. szakirodalom-kutatás

4. vitatkozó módszer

5. kérdező módszer

6. konzultáció 


\section{Szemléltető (megfigyelésen alapuló) mód- szerek:}

1. modellezés

2. szimuláció

3. poszteres, ill. prezentációs feldolgozás

4. vetítés

5. tanulmányi kirándulások, üzem- vagy céglátogatások, ill. szakkiállítások megtekintése

\section{Gyakorlati (tevékenységen alapuló) mód- szerek:}

1. kísérletezés

2. laboratóriumi mérés

3. begyakorlás

4. szakmai, üzemi gyakorlatok

\section{Komplexebb (szintetizáló) módszerek:}

1. programozott (táv)oktatás

2. problémafelvető (projektalapú) oktatás

3. algoritmusoktatás

\section{A felsorolt módszerek jellemzői}

Az előadásra jellemző az oktató kiemelt szerepe és határozottan aktív magatartása az oktatási folyamat megszervezésében és lebonyolításában, a hallgatók „fogyasztói” magatartása mellett.

A tankönyv, illetve jegyzet - mint bemutatással (ábrák, fotók, diagramok, táblázatok) kiegészített „nyomtatott előadás” - kész formában közli a hallgatókkal az elsajátítandó ismereteket. Itt a hallgató a közölt ismeretek „passzív” befogadója.

A szakirodalom-kutatás fontos tényezője az egyre bővülő ismeretanyag adott tanórakeretbe már be nem építhető része feldolgozásának és az önálló tudományos munkára való nevelésnek. A tudományok specializáltsága miatt ennek legjobb lehetőségei az intézményi és online könyvtárakban vannak meg. Például egy jól szervezett szakfolyóirat-gyüjtemény révén a szakterületi információk naprakészen áll(hat)nak az irodalomkutatók rendelkezésére.

A vitatkozó módszer lényege, hogy az oktató felveti a megoldásra váró problémát, és a hallgatók megfogalmazzák azzal kapcsolatos nézeteiket. Az oktató - aki a vita egyik egyenrangú résztvevőjeként kapcsolódik be a foglalkozásba - csak irányító szerepet tölt be. Ez a módszer főként a szemináriumok jellemzője, de más keretek között is alkalmazható.

A kérdező módszer esetében a foglalkozásokat egy megfelelően összeállított kérdéssor segítségével bonyolítják le. A „moderátori” kérdéssor bevezető vagy előkészítő, rávezető és összegző, vagyis a feldolgozott téma összefoglaló és szintetizáló kérdésekből áll(hat).

A konzultációk a hallgatók munkájában való segítségnyújtás tanrenden kívüli formái, az adott tantárgy tanulásával, illetve a tudományág alaposabb megismerésével kapcsolatos tanácsok formájában valósulnak meg. A konzultációk köre és jellege nagyon differenciált lehet. Az alsóbb évfolyamokon a nehezebb tananyagrészek megértéséhez, a felsőbb évfolyamokon viszont már tudományos feladatok (pl. TDK, szakdolgozat, diplomaterv) megoldásához is kérik a hallgatók a konzultációs segítséget.

A modellezés, modellalkotás a tananyag-feldolgozás fontos eszköze, ami tulajdonképpen a kapcsolódó tudományágnak is fő jellemzője. Bonyolult szerkezetek, (szub)mikroszkopikus objektumok és folyamatok, rendkívül rövid ideig tartó jelenségek stb. csak így válhatnak jól követhetőkké, érthetőkké. Természetesen a modellt kellő kritika alá kell vetni „bevezetése” előtt, és meg kell állapítani a valósággal való korrelációjának mértékét. Az ilyen modellek nagy része tárgyiasult formában is megjeleníthető, mint szemléltetőeszköz. A makettek is idesorolhatók, amelyek azonban nem egyszerüsítik, hanem kicsinyített változatban többé-kevésbé leképezik a valóságot.

Példának okáért a geometriai krisztallográfia szemléltetési lehetőségei lehetnek [3]:

- A síkbeli grafikus modellek, amelyek a kristályrácselemeket leggyakrabban kétdimenziós axonometrikus drótváz, húrcsomópont vagy golyóábrákkal szemléltetik. Előnyük az olcsó „előállítás”, a kis helyigény és a nagyfokú mobilitás. De bármilyen szépek és térhatásúak is ezek az ábrák, főleg az összetettebb celláknál és rácsoknál nem áttekinthetőek, és nem mindig adnak egyértelmű választ a térbeli felépítésre, az allotróp átalakulások lehetőségére.

- A térbeli épített modellek (makettek), amelyek az előbbi csoport továbbfejlesztett térbeli változatai. Például ilyenek a gyárilag előállított (rendszerint műanyagból készült) demonstrációs modellek és építőkészletek. Ezek helyettesíthetők „házilag barkácsolt” golyó-drótváz (általában fém, müanyag és fa alapanyagú) vagy ragasztott ping-pong-labda-modellekkel. Előnyük az igényes megjelenés és az, hogy a hallgatók fizikailag is megfoghatják, közelről megnézhetik. Hátrányuk a sérülékenység, a költségesség és az, hogy a hallgató nem tud bármikor hozzáférni.

-A háromdimenziós számítógépes statikus modellek, amelyek ötvözik az előző két csoport tulajdonságait, és a kétdimenziós monitoron 
háromdimenziós objektumokként, felületekként jelennek meg. Nem megfoghatók ugyan, de térben elforgathatók, kicsinyíthetők, nagyíthatók. Nagy előnyük, hogy tetszőleges beállítású kétdimenziós kép menthető el róluk, így az első csoport létrehozásához is felhasználhatók. Adathordozón korlátlanul sokszorosíthatók, hálózaton keresztül is eljuttathatók bárhová, ami nagyfokú „mobilitást” biztosít. Viszonylag kis helyet foglalnak és prezentációkban is felhasználhatók, remek lehetőségeket nyújtva az oktatásban. Hátrányuk, hogy a sok felületelemből álló objektumok renderelése (az a funkció, amikor a megszerkesztett médiát vágásokkal, effektekkel, feliratokkal stb. a kívánt formátumban elkészíti, vagyis kiszámolja a program, majd menti a „végterméket”) esetenként igen erős hardvert igényel.

- A háromdimenziós számítógépes animációk, amelyek a leglátványosabbak, de a legfejlettebb hardver- és szoftverhátteret igénylik. Segítségükkel a legbonyolultabb rácsátalakulások és torzulások is szemléletesen bemutathatók. Szintén „hordozhatók” (pl. pendrive-on, memóriakártyán), bár több tárhelyet foglalnak, mint a statikus modellek.

A szimuláció is egyfajta modell, de tipikusan folyamatokat, tehát nem kiragadott pillanatnyi állapotokat szemléltet. Különösen népszerűek és sokoldalúak a számítógépi szimulációk, melyeknek főbb lépései [4]:

- probléma megfogalmazása, újrafogalmazása (figyelembe veendő tényezők meghatározása, szűkítése-bővítése);

- modellépítés és -fejlesztés (egyszerübbtől haladva a bonyolultabb felé);

- szükséges adatok összegyűjtése (befolyásoló hatásuk mértékének figyelembevételével);

- rendszermodell elkészítése, kódolása (algoritmizálás, programozás);

- ellenőrzés (lépésről lépésre), stabilitásvizsgálat (szélsőséges, illetve gerjesztő paraméterekkel is), értékelés (érvényességi kör, pontosság);

- szimulációs kísérleti vizsgálatsor megtervezése; - szimulációs modell használata, „futtatása”;

- eredmények elemzése, értékelése;

- eredmények dokumentálása, felhasználása.

A poszteres, illetve prezentációs feldolgozás egyegy tananyagegység tömören összefoglalt változata. Szemléltetőerejét az esztétikus, logikus felépítés és a beleszerkesztett ábrák, fotók, diagramok, táblázatok adják. A korszerű témát feldolgozó poszterek (tablók) nemcsak egyszerű szemléltetőeszközök lehetnek a foglalkozások keretében, ha- nem tanszéki dekorációs, illetve kiállítási célokat is szolgálhatnak.

A vetítés módszere magában foglalja a vizuális szemléltetés, illetve a megfelelő eszközök legnagyobb részét. Régebben eszközparkjához az írásvetítő, a diavetítő, a mozgófilmvetítő, a videomagnetofon tartozott. Ezeket együttesen felváltotta a számítógép-projektor kombináció. Ezen módszerrel - célszerúen elkészített médiafájlokkal - lehet a legsokoldalúbb és egyben legnagyobb információsűrűségű szemléltetést (adott időkeretben) biztosítani. Éppen ezért használatakor figyelembe kell venni azt is, hogy ezt a nagy mennyiségü információt nem lehet teljes egészében elsajátítandó tananyagnak tekinteni, hanem célszerű szempontokat adni a lényeg megragadásához.

A tanulmányi kirándulások, üzem- vagy céglátogatások, illetve a szakkiállítások megtekintése is az oktatás szervezeti formái közé tartoznak, és éppen ezért teljes értékű tanulmányi munkának tekintendők. Nem szoríthatók ki teljesen videófelvételek „bevetésével”, hiszen az üzemi légkörről, a térbeli valóságról a legjobb felvételek sem nyújtanak teljesen reális képet, nem beszélve az időbeli tömörítettségükről.

Az [5] közlemény egy olyan - elsősorban hegesztés iránt érdeklődő hallgatóknak, szponzori támogatásokkal szervezett - 15 napos, 6 országot érintő, autóbuszos, nyugat-európai szakmai körútról számol be, amelynek keretében 11 elismert céget (Fronius, Audi, SLV, Oerlikon, Castolin, TWI, Soudometal, RWTH, Cloos, Voest-Alpine, Interweld), illetve azok tevékenységét sikerült „testközelből” megismerni. A sok értékes tapasztalaton és prospektuson kívül kulturális élményekben is gazdagodtak a résztvevők, ugyanis a szakmai programok mellett városnéző túrákra is maradt idő, többek között Salzburg, Ulm, Zürich, Lausanne, Párizs, Versailles, Cambridge, London, Brüszszel, Köln, Frankfurt am Main, Nürnberg, Linz nevezetességeit felkeresve.

A begyakorló foglalkozások és a szakmai, üzemi gyakorlatok főként a manuális készségek (rajzolás, berendezések kezelése, valamilyen tárgyak előállítása, illetve vizsgálata stb.) fejlesztését szolgálják. Amíg a begyakorló foglalkozások iskolai tanmühelyekben (laborokban) kerülnek lebonyolításra, addig a szakmai gyakorlatok vállalatoknál, tehát „élesben” mennek. A műszaki felsőoktatásban különös fontossággal bírnak a tantermi és a laboratóriumi gyakorlati foglalkozások. Egy korábbi [6] közleményünkben ezek szerepéről, funkcióiról, formáiról és tartalmi szerkezetéről már áttekintést adtunk. 
A programozott és a problémafelvető oktatás legfontosabb sajátosságait - összehasonlítva a közlő oktatás jellemzőivel - az 1. táblázat foglalja össze [1, 2].

A programozott (táv)oktatás módszerének célja az oktatási folyamat individualizálása és automatizálása. Lényege maga a távoktatási tananyag, amely egymással logikai és tartalmi összefüggésben álló információadagok sora, amelyet a hallgatóknak el kell sajátítaniuk a megfelelően összeállított, számítógépen futó „tankönyv” segítségével.

A problémafelvető (projektalapú) oktatás a kooperatív, kollaboratív és autonóm tanulás, illetve a tanulói motivációra épülő pedagógiai irányzatok, módszerek szintézise és a tanulási folyamatban a tanulói aktivitás kulcsszerepet játszik, illetve az elsődleges oktatói (tanári) szerepkör is módosul. Az oktató a tradicionális tanári szerepet a koordináló, moderátori szerepre cseréli fel. A megoldandó projektfeladatok (felvetett prob- lémák) megközelítését az interdiszciplinaritás jellemzi.

A tanítás algoritmusa olyan módszeres tanítási eljárás, mely szerint minden egyes lépésnek az egész rendszeren belül olyan meghatározott helye van, hogy bármelyik pontból egy meghatározott döntés alapján minden esetben el lehet jutni a következő oktatási lépéshez.

$\mathrm{Az}$ algoritmusok oktatásának ott van jelentősége, ahol a tanulóknak nagyszámú (gyakran ismeretlen végeredményü) feladatot kell megoldani, és ezen feladatok jó megoldási algoritmusait nem könnyű felfedezni, illetve annak következtében komoly nehézségek támadhatnak az ismeretek elsajátításában.

\section{Következtetés}

A felsőoktatás, azonbelül a mérnökképzés didaktikai, módszertani folyamatát úgy célszerű

\begin{tabular}{|c|c|c|c|}
\hline & $\begin{array}{c}\text { Közlö } \\
\text { oktatás }\end{array}$ & $\begin{array}{l}\text { Programozott } \\
\text { (táv)oktatás }\end{array}$ & $\begin{array}{c}\text { Problémafelvetö (projektalapú) } \\
\text { oktatás }\end{array}$ \\
\hline 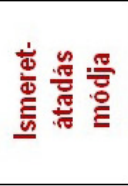 & $\begin{array}{l}\text { A tananyagot az oktató kész } \\
\text { formában adja át. } \\
\text { Elsôsorban a tantervre, ill. a } \\
\text { tematikára figyel és ez „elfedi } \\
\text { szeme elöl" a hallgatókat. }\end{array}$ & $\begin{array}{c}\text { A tananyag közlésének módja } \\
\text { állandó aktivitásra kényszeríti a } \\
\text { hallgatókat. } \\
\text { Maguk a hallgatók állnak az } \\
\text { oktatás középpontjában. }\end{array}$ & $\begin{array}{l}\text { A hallgatók elméleti és gyakorlati } \\
\text { problémák megoldása útján } \\
\text { szerzik az új ismereteket. }\end{array}$ \\
\hline 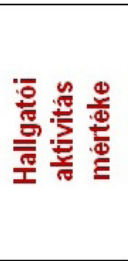 & $\begin{array}{l}\text { A verbális vagy a tankönyv útján } \\
\text { történô közlésben hiányok, } \\
\text { akadályok és nehézségek } \\
\text { merülnek fel, aminek oka többek } \\
\text { között a hallgatók „átmeneti } \\
\text { kikapcsolása” az oktatási } \\
\text { folyamatból. }\end{array}$ & $\begin{array}{c}\text { A tananyag programozása olyan, } \\
\text { hogy nincsenek benne hiányok } \\
\text { és nehézségek. } \\
\text { Az elörehaladáshoz a } \\
\text { hallgatóknak minden akadályt le } \\
\text { kell küzdeniük. }\end{array}$ & $\begin{array}{l}\text { A probléma megoldása során a } \\
\text { hallgatóknak minden akadályt le } \\
\text { kell küzdeniük, aktivitásuk és } \\
\text { önállóságuk itt a legnagyobb. }\end{array}$ \\
\hline 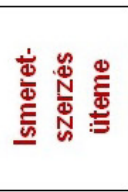 & $\begin{array}{l}\text { A közlés ütemének a jobb, } \\
\text { közepes vagy gyengébb } \\
\text { hallgatókhoz egyaránt } \\
\text { alkalmazkodnia kell. }\end{array}$ & $\begin{array}{l}\text { A tanulás üteme kizárólag a } \\
\text { hallgatóktól függ, hiszen } \\
\text { egyénileg dolgoznak. }\end{array}$ & $\begin{array}{l}\text { A tanulás üteme az egyes } \\
\text { tanulóktól, vagy azok } \\
\text { csoportjaitól (team) függ. } \\
\text { A gyengébb hallgatóknak } \\
\text { elönyös a csoportmunka. }\end{array}$ \\
\hline 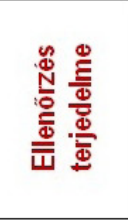 & $\begin{array}{l}\text { Az oktatási eredmények } \\
\text { ellenörzése részleges, nem } \\
\text { szerves része az ismeretek } \\
\text { átadásának. }\end{array}$ & $\begin{array}{c}\text { Az ellenörzés teljes és a tanulás } \\
\text { szerves része. } \\
\text { A hallgatók nem léphetnek } \\
\text { elöbbre anélkül, hogy ne } \\
\text { ellenöriznék, tudják-e a } \\
\text { tananyagot. }\end{array}$ & $\begin{array}{l}\text { A hallgatók nagyobb fokú } \\
\text { aktivitása és a tanulás pozitiv } \\
\text { motivumainak fejlödése } \\
\text { csökkenti a teljes körü ellenörzés } \\
\text { szülkségességét. }\end{array}$ \\
\hline 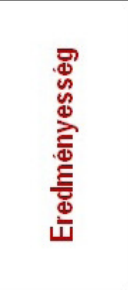 & $\begin{array}{c}\text { Nem lehet százszázalékos } \\
\text { oktatási eredményt biztositani } \\
\text { valamennyi hallgató számára, de } \\
\text { az így szerzett ismereteket a } \\
\text { hallgatók rendszerint } \\
\text { könnyebben alkalmazzák, mint a } \\
\text { programozott (táv)oktatás } \\
\text { esetében. }\end{array}$ & $\begin{array}{c}\text { Tekintettel a rendszeres } \\
\text { ellenörzésre, az oktatás } \\
\text { eredményei jobbak, mint a közlö } \\
\text { oktatásnál, az ismeretek } \\
\text { alkalmazásának képessége } \\
\text { azonban kevésbé jó. }\end{array}$ & $\begin{array}{c}\text { Az oktatás eredményei } \\
\text { viszonylag jók. } \\
\text { A hallgatók sok ismeretet } \\
\text { szereznek, könnyen alkalmazzák } \\
\text { öket új helyzetekben. } \\
\text { Egyúttal fejlödik megismerō } \\
\text { készségük, szakmai } \\
\text { érdeklödésük is. }\end{array}$ \\
\hline
\end{tabular}


irányítani, hogy a hallgatók értsék a képzés célját és saját felelősségüket azok megvalósításában, kialakuljon bennük a pozitív motiváció és az önellenőrzés, illetve ne legyenek a kész ismeretek paszszív fogyasztói, hanem annak aktív teremtőivé is váljanak. Ezért fontos a módszertani eszköztár ismerete és azonbelül a hallgatói aktivitásra alapozó módszerek előtérbe helyezése.

\section{Szakirodalmi hivatkozások}

[1]Okoň W.: Felsőoktatási didaktika. Felsőoktatási Pedagógiai Kutatóközpont, Budapest, 1973.

[2] Kietliňskja Z:: A müszaki felsőoktatás pedagógiája. Felsőoktatási Pedagógiai Kutatóközpont, Budapest, 1974.
[3] Bagyinszki Gy., Tar A.: Anyagok szubmikroszkópikus és makroszkópikus krisztallográfiája. Anyagok Világa (Materials World) - Független Elektronikus Szakmai Folyóirat, 7/2. (2007).

[4] Bagyinszki Gy., Bitay E.: Bevezetés az anyagtechnológiák informatikájába. Erdélyi Múzeum-Egyesület, Kolozsvár, 2007. https://doi.org/10.36242/mtf-03

[5] Bagyinszki Gy.: Fiatal szakemberjelöltek NyugatEurópában. Gép 40/1. (1992) Február, 19-21.

[6] Bagyinszki Gy., Bitay E.: Anyagtudományi gyakorlat-modulok a gépész- és mechatronikai mérnök képzésben. In: Fiatal műszakiak tudományos ülésszaka XVI., Kolozsvár, Románia, Műszaki Tudományos Füzetek 2011. 5-16.

https://doi.org/10.36243/fmtu-2011.04 